\title{
A Sublingual Neurofibroma: A Case Report
}

\author{
Ahmet ALTAN (D), Aras ERDİL (D), Nihat AKBULUT (1)
}

\begin{abstract}
Neurofibromatosis is a genetically inherited, autosomal dominant disorder. Deletions or mutations on chromosomes 17 and 22 precipitate to neurofibromatosis and there are genetically two types of the it as Type 1 and Type 2. Neurofibromatosis Type 1 is relevant with the abnormalities on chromosome 17.

In the affected population, the incidence of oral manifestation is as high as $92 \%$, and the tongue is the most common involved site. Due to the lack of neurofibromin, which is encoded by the NF1 gene located on chromosome 17 and acts as a tumor suppressor protein, neurofibromas are frequently diagnosed on the tongue as nodular growths or diffuse macroglossia in the oral cavity.

In this case report we aim to present our approach of treatment with intent to meet patient's preprosthetic demands by performing an incisional biopsy on a sublingual neurofibroma and review the current literature in terms of diagnostic criteria, clinical features, accompanying impairments and treatment modalities.
\end{abstract}

$\ddot{\mathrm{O} z}$

Nörofibromatozis genetik olarak aktarılan, otozomal dominant bir hastalıktır. Hastalığın oluşumuna 17. Ve 22. kromozomlardaki delesyonlar (silinme) veya mutasyonlar sebep olmakta ve hastalığın tip 1 ve tip 2 olmak üzere iki türü bulunmaktadır. Nörofibromatozis Tip 1, 17. kromozomdaki anomalilerden kaynaklanmaktadır.

Etkilenen popülasyonda oral bulguların görülme sıklığı \%92'ye kadar yükselmektedir. Dil, oral bölgede en s1k etkilenen organdır. Hasta bireylerde, tümör baskılayıcı bir protein olan ve 17. kromozom üzerinde yer alan, NF1 geni tarafından kodlanan nörofibromin üretilmediği için oral kavitede sıklıkla dilde

\author{
Ahmet ALTAN \\ Tokat Gaziosmanpasa University, Faculty of Dentistry, Oral and \\ Maxillofacial Surgery Department \\ Aras ERDİ ( $\varangle)$ \\ Tokat Gaziosmanpasa University Faculty of Dentistry, Oral and \\ Maxillofacial Surgery Department \\ e-mail:erdil.aras@gmail.com \\ Nihat AKBULUT \\ Tokat Gaziosmanpasa University, Faculty of Dentistry, Oral and \\ Maxillofacial Surgery Department
}

Submitted / Gönderilme: 30.05 .2019

Accepted / Kabul: 30.12 .2019 nodüler büyümeler şeklinde veya diffüz makroglossi tarzında nörofibromalar görülmektedir.

Bu olgu sunumunda, Nörofibromatozis Tip 1 tanılı hastada bir sublingual nörofibromaya insizyonel biyopsi ile preprotetik amaçlı tedavi yaklaşımımızı sunmayı ve mevcut literatürü tanı kriterleri, klinik özellikler, eşlik eden bozukluklar ve tedavi yöntemleri açısından gözden geçirmeyi amaçladık.

\section{INTRODUCTION}

Neurofibromatosis is a genetic disorder and inherited autosomal dominantly. Although there are case reports in the literature; in 1793 Tilesius and in 1849 Robert W. Smith, it was first diagnosed by a German pathologist Friedrich Daniel von Recklinghausen in $1882 .{ }^{1}$

Genetically, Neurofibromatosis is subdivided into three types: Neurofibromatosis Type-1 (NF1), Neurofibromatosis Type-2 (NF2) and Schwannomatosis. ${ }^{2,3}$ The underlying etiological factors for Type-1 and 2 are NF1 and NF2 genes deletions or mutations on chromosome 17 and 22 respectively. ${ }^{4}$ Schwannomatosis is a more recently described form of neurofibromatosis and is distinguished from NF2 by the lack of vestibular tumors. ${ }^{3}$ These deletions and mutations can be inherited by autosomal dominantly or arisen from spontaneous mutations. NF1 has the most frequent spontaneous mutation rate among other genetic disorders. Broadly $50 \%$ of NF1 patients have a positive family history, and the other $50 \%$ have spontaneous mutations. $^{5}$

NF1, also known as von Recklinghausen or peripheral neurofibromatosis is affecting 1 in 2000-3000 individuals; however, in the mentally retarded population, the incidence rises to 1 in 200 individuals. ${ }^{6}$ It is known that up to $96 \%$ of all Neurofibromatosis cases are Type- $1 .{ }^{7}$ NF1 diagnostic criteria were determined at the Consensus Conference on 
Neurofibromatosis in 1987 by National Institutes of Health (NIH) and were updated in 1997. (Table 1) In order to diagnose the NF1, at least two or more of the criteria listed in table 1 should be met. ${ }^{2}$ However, it was stated that diagnosis according to these criteria in young children cannot always be made and in most children by 8 years old diagnosis can be accurately made. ${ }^{8}$

Table 1. (Page 3): Diagnostic Criteria For Neurofibromatosis Type $1^{2}$

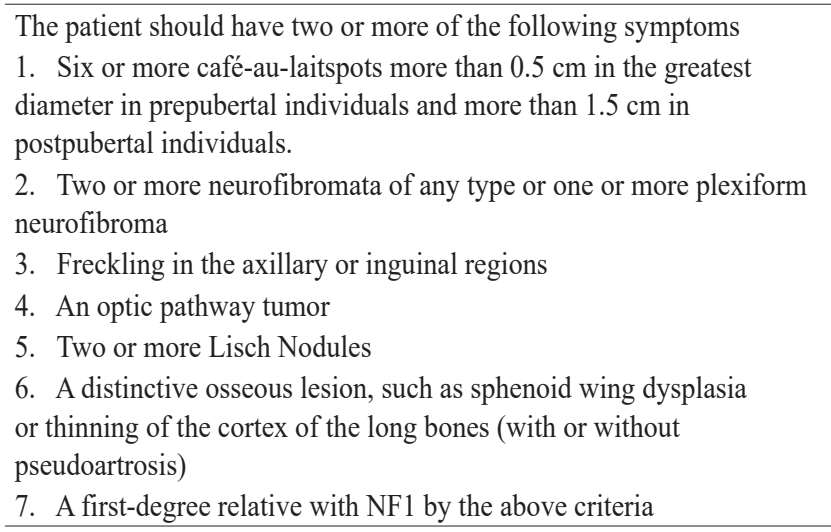

NF1 is an autosomal dominantly inherited neurocutaneous disease with melanin pigmentations on the skin, neurofibromas, iris hamartomas and skeletal-nervous system defects. Since NF1 was classified as a tumor predisposition syndrome individuals with this syndrome harbour the elevated risk of development malign and benign tumors on peripheral nerves. ${ }^{9,10}$ Besides that features, oral manifestations can be seen up to $92 \%$ of NF1 patients. ${ }^{5}$ The tongue, buccal mucosa, alveolar crest, gingiva, lips, the floor of mouth, palatal and pharyngeal regions are the common involved sites in oral cavity. ${ }^{5,11}$

In this case report, we aimed to present a NF1 which was detected in a female patient, at the right sublingual region as a nodular mucosal growth attached to the tongue and the floor of mouth, and treated with incisional biopsy to meet the prosthetic demands of the patient and review of the literature.

\section{CASE REPORT}

A 53-year-old female patient was referred to the clinic for a speech impediment and prosthetic demand. Due to her medical history, she was diagnosed with $\mathrm{NF} 1$ at the age of 45. Familial questioning revealed that there was not any other relative diagnosed with any genetic disorder. This fact made us think that the disease has arisen from a spontaneous mutation. There were multiple Lisch nodules on each eye. During extraoral examining we detected some cutaneous lesions on the perioral region (Figure 1A) and two café-aulait spots on each forearm. However, any axillary freckling or apparent maxillofacial asymmetry were not detected. Intraoral examination revealed an oversized soft tissue mass which was nodular shaped, fibrous consistency, mucosa coloured, and pedicellated to the right side of the tongue and floor of the mouth.(Figure 1B)
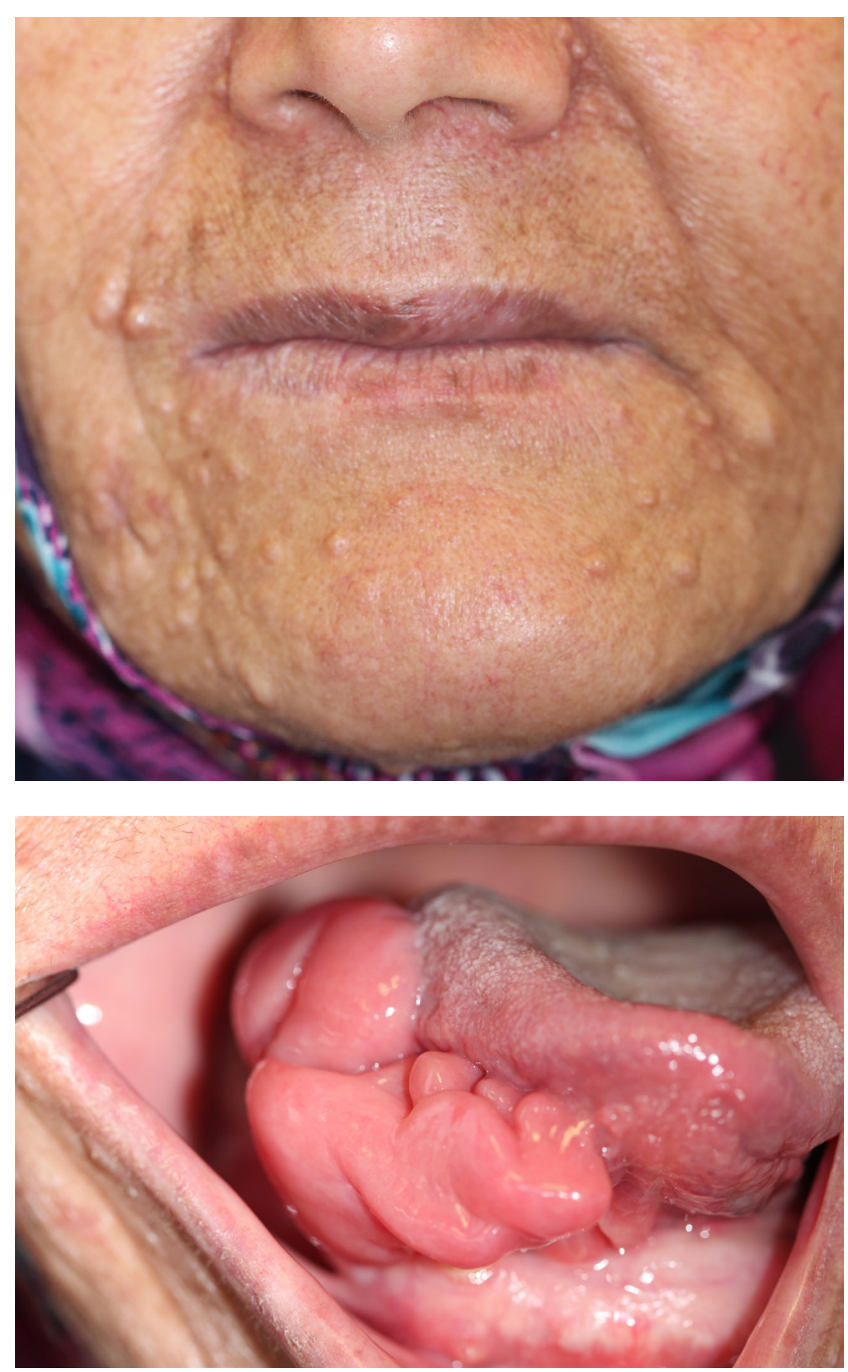

The mass displaced the tongue to the contralateral site. In the rest position, the mass was covering the occlusal surfaces of the lower right canine, first and second premolars.

In the radiological examination, some pathognomonic alterations like the widening of mandibular canal and mental foramen, deepening of sigmoid notch were detected. (Figure 1C) 


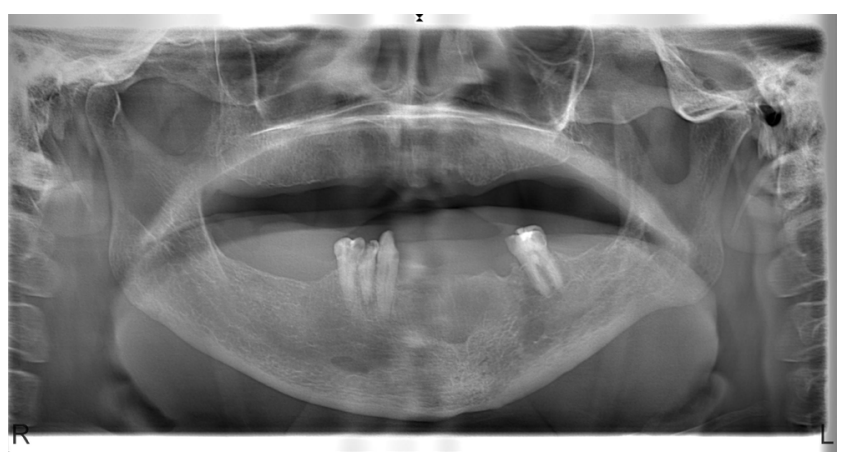

Figure 1. Preoperative clinical and radiologic views of the patient $(1 \mathrm{~A}, 1 \mathrm{~B}, 1 \mathrm{C})$

Concerning patient's demands a simple incisional biopsy, which would reduce the size of the lesion and would let us perform a pathological examination, was planned under local anaesthesia. To avoid bleeding complication and recontour the tongue, the three specimens were excised in sizes of $3.5 \times 2 \times 1,2 \times 1 \times 1$ and $2 \times 1 \times 1 \mathrm{~cm}$. The lateral border of the tongue was sutured primarily with 3-0 silk sutures.

(Figure 2A-2B)
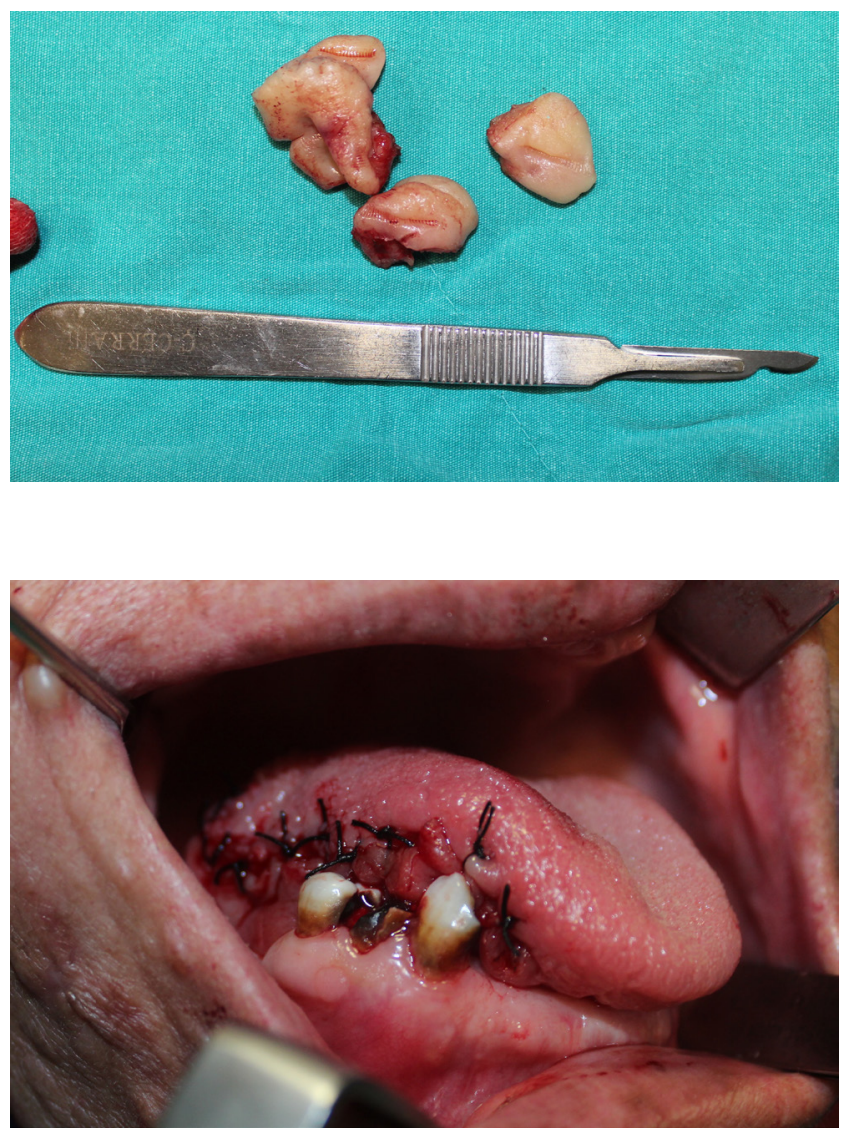

Figure 2. Intraoperative views of the patient (2A, 2B)
In the pathological examination histomorphological and immunohistochemical analyses revealed that the mass was a neurofibroma.

The tongue healed uneventfully. The patient was followed up to one year and her speech improved. A new denture was manufactured by her general dental practitioner. The size of the remnant lesion, which was left on the floor of the mouth, did not increase during the follow up period. (Figure 3A and 3B) The patient is still being followed-up annually for the risk of malignant transformation.
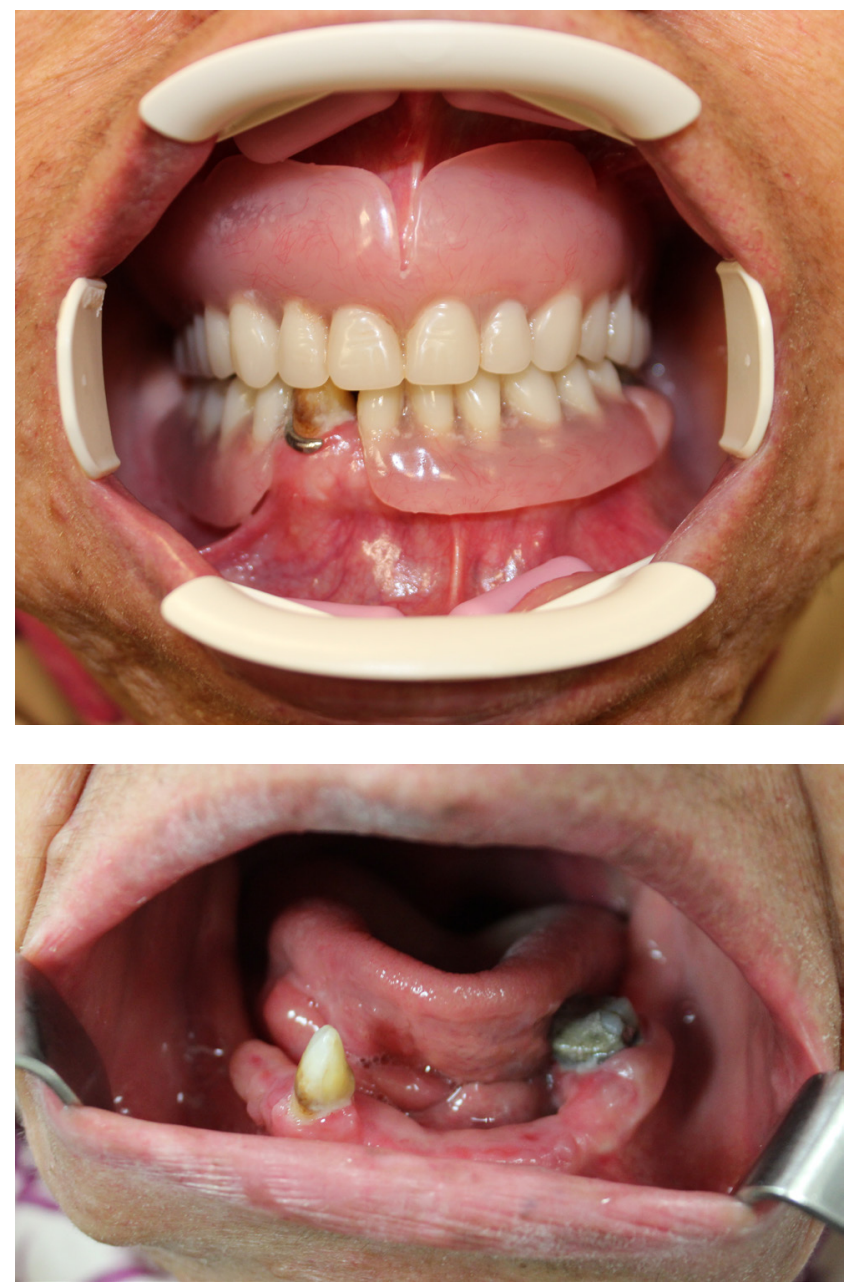

Figure 3. Intraoral views after one year follow up period (3A, 3B)

\section{DISCUSSION}

NF1 is an inherited disorder with the presence of peripheral neurofibromas, café-au-lait macules, and axillary freckling. Also, bone metabolism disorders like skeletal dysplasia, 
bowing, pathologic fractures and pseudoarthrosis may be detected in NF1 patients. ${ }^{12}$

Diseases seen as a result of mutations in genes encoding Ras/mitogen activated protein kinase (Ras/MAPK) pathway are called RASopathies and Neurofibromatosis is one of these diseases. ${ }^{13}$ Neurofibromin is a cytoplasmic protein and is expressed in neurons, Schwann cells, oligodendrocytes and leukocytes. It is a multifunctional enzyme and regulates intracellular activities like RAS-Cyclic AMP pathway, ERK/ MAP kinase cascade, adenylyl cyclase enzyme function and cytoskeleton formation. ${ }^{14}$ Neurofibromin acts as Ras GTPase activator protein thus has a tumor suppressor function. ${ }^{15}$ Neurofibromin mRNA and protein were also detected in human osteoblast and osteoclast cells. ${ }^{16} \mathrm{Hence}$, skeletal abnormalities are seen in $40-50 \%$ of the NF1 cases due to malformation of this protein., ${ }^{4}, 17$ These osseous symptoms are: low bone mineral density, short stature, macrocephaly, sphenoid wing dysplasia, congenital pseudoarthrosis and dystrophic scoliosis. ${ }^{18}$

In the past, oral symptoms of neurofibromatosis was thought to be scarce. However, with advancements in diagnostic techniques oral involvement frequency in NF patients rose up to $72 \%$ and $92 \%$ according to Shapiro et $a l .{ }^{11}$ and D'Ambrossio et al. ${ }^{5}$, respectively.

The most seen oral symptom is the enlargement of the fungiform papillae with a $5 \%$ incidence. Nonetheless, the tongue is the most common site in the oral cavity where oral neurofibromas are diagnosed. ${ }^{5,11,19}$ Bongiornoet al. ${ }^{20}$ reported that neurofibromas in the tongue were almost always nodular, but there are also cases of diffuse macroglossia. To the best of our knowledge, Robert Smith first reported a neurofibroma on the tongue of a NF1 patient. ${ }^{1}$ Although, Zoller et al. ${ }^{21}$ stated four times more tumor formation in NF1 population, in the differential diagnosis of tumoral tongue masses, angiolipoma, myolipoma, hamartomatous lesions, schwannoma, lymphangioma, granular cell tumor, fibroma, leiomyoma, rhabdomyosarcoma, hemangioma, neurofibroma and plexiform neurofibroma should be considered.

There are also pathognomonic alterations on maxillofacial radiographs. In 1988, Sailer et al. ${ }^{22}$ designated 12 specific alterations on mandible in NF1 patients. These are listed in Table 2. Lorson et al. ${ }^{23}$ stated that form distortion of the sigmoid notch was a remarkable feature. Shapiro et al. ${ }^{11}$, D'Ambrosio et al. ${ }^{5}$, Kaplan et al. ${ }^{24}$ and Visnapuu et $a l .{ }^{25}$ reported that the most common radiological alterations were widening of the mandibular canal and enlargement of the mental foramen. D'Ambrosio et al. ${ }^{5}$ revealed $24 \%$ widening of mandibular canal, $34 \%$ enlargement of the mental foramen and $24 \%$ branching of the mandibular canal in their study population.

Table 2. (Page 8):Twelve Pathognomonic Features Of The Mandible In NF Patients ${ }^{22}$

1. Deviation of the mandible to the affected side

2. Minimal swelling of cheek or intraoral soft tissue

3. A coronoid notch deformity (inferiorly displaced)

4. Pseudoelongation of condylar/coronoid process

5. Deformity hypoplasia of the ascending ramus with perforation defects

6. Flat or absent gonial angle

7. Deformity or hypoplasia of the body of the mandible

8. Impacted teeth on the affected side of the mandible

9. Hypoplasia of the ipsilateral maxilla and zygoma

10. Impacted teeth in the ipsilateral maxilla

11. Reduced translation of the condyle of the affected side

12. External ear deformity (inferiorly displaced)

According to current literature, there is no direct correlation between oral health status and oral neurofibromas. ${ }^{26}$ Nevertheless, dental anomalies, impacted, displaced, supernumerary or missing teeth partially on mandible and overgrowth of the alveolar crests are frequently reported features in NF1 patients. ${ }^{5,11,27}$ Moreover, Visnapuu et al. ${ }^{28}$ reported that periapical cemental dysplasia was more common in patients with NF1 and claimed that they unveiled a gender-specific symptom for the first time because most of these patients were female. On the other hand, Friedrich and Reul ${ }^{29}$ reported that they could not reveal any gender predilection or incidence rate increase in their study population, consisting of 179 NF-1 diagnosed patients.

If oral neurofibromas alter, the functions of the oral cavity, surgical intervention is usually required. ${ }^{30}$ On the other hand, if the neurofibroma does not cause clear obstacles or if the patient's condition is not improved by surgery, they should not be annihilated. Contrary to previous views, there is no evidence that surgical interventions increase the risk of malignancy. ${ }^{20}$ However, the rapid growth of neurofibromas and the occurrence of pain are suspected at malign transformation. ${ }^{9}$ Malignant peripheral nerve sheath tumors may develop from plexiform neurofibromas. Malignant transformation has been reported in $1-29 \%$ of cases and is one of the leading causes of cancer-related deaths in NF1 patients. ${ }^{20}$ 


\section{CONCLUSION}

Although the conditions of oral lesions are not directly correlated with oral health, a disease affecting multi-system such as NF1, combined with oral and dental anomalies, causes serious disability in patients. Therefore, patient education and regular controls in terms of oral hygiene are important for oral health of the patient. ${ }^{26}$ The rapid growth of the masses, compression or infiltration to the adjacent tissues should induce suspicion of malignancy and close follow up with further radiologic techniques like CT and MR should be performed. The masses affecting oral function should be controlled by annual follow-up due to the risk of malignant transformation by surgical intervention in line with patient expectations.

Conflict of Interest: None declared.

\section{REFERENCES}

1. Ba MR, Caltabiano R, Polizzi A. Early history of the different forms of neurofibromatosis from ancient Egypt to the British Empire and beyond : First descriptions, medical curiosities , misconceptions, landmarks, and the persons behind the syndromes. 2018;(June 2017):515-550. doi:10.1002/ ajmg.a.38486

2. Gutmann DH, Aylsworth A, Carey JC, et al. The diagnostic evaluation and multidisciplinary management of neurofibromatosis 1 and neurofibromatosis 2. JAMA. 1997;278(1):51-57.

3. MacCollin M, Chiocca EA, Evans DG, et al. Diagnostic criteria for schwannomatosis. Neurology. 2005;64(11):18381845. doi:10.1212/01.WNL.000.016.3982.78900.AD

4. Patel NB, Stacy GS. Musculoskeletal manifestations of neurofibromatosis type 1. AJR Am J Roentgenol. 2012;199(1):W99-106. doi:10.2214/AJR.11.7811

5. D'Ambrosio JA, Langlais RP, Young RS. Jaw and skull changes in neurofibromatosis. Oral Surgery, Oral Med Oral Pathol. 1988;66(3):391-396. doi:10.1016/00304220(88)90252-6

6. Bekisz O, Darimont F, Rompen EH. Diffuse but unilateral gingival enlargement associated with von Recklinghausen neurofibromatosis: a case report. $J$ Clin Periodontol. 2000;27(5):361-365.

7. Ferner RE. Neurofibromatosis 1 and neurofibromatosis 2: a twenty first century perspective. Lancet Neurol. 2007;6(4):340-351. doi:10.1016/S1474-4422(07)70075-3

8. DeBella K, Szudek J, Friedman JM. Use of the National Institutes of Health criteria for diagnosis of neurofibromatosis 1 in children. Pediatrics. 2000;105(3):608-614. doi:10.1542/ peds.105.3.608

9. Vincent SD, Williams TP. Mandibular abnormalities in neurofibromatosis. Case report and literature review. Oral Surg Oral Med Oral Pathol. 1983;55(3):253-258.
10. Oliveira MG De, Moure SP. NF1 diagnosis criteria and associated sarcomatous tumor review of the literature and case report. 2008:231-235. doi:10.1007/s10006.008.0137-1

11. Shapiro SD, Abramovitch K, Van Dis ML, et al. Neurofibromatosis: oral and radiographic manifestations. Oral Surg Oral Med Oral Pathol. 1984;58(4):493-498. http://www.ncbi.nlm.nih.gov/pubmed/6436765. Accessed February 4, 2019.

12. van Damme PA, Mooren RE. Differentiation of multiple giant cell lesions, Noonan-like syndrome, and (occult) hyperparathyroidism. Case report and review of the literature. Int J Oral Maxillofac Surg. 1994;23(1):32-36.

13. Cao H, Klein NAOD, Goodwin AF. A review of craniofacial and dental findings of the RASopathies. 2017;20(February):32-38. doi:10.1111/ocr.12144

14. Trovo-Marqui AB, Tajara EH. Neurofibromin: a general outlook. Clin Genet. 2006;70(1):1-13. doi:10.1111/j.13990004.2006.00639.x

15. Bollag G, Clapp DW, Shih S, et al. Loss of NF1 results in activation of the Ras signaling pathway and leads to aberrant growth in haematopoietic cells. Nat Genet. 1996;12(2):144148. doi:10.1038/ng0296-144

16. Leskela H-V, Kuorilehto $\mathrm{T}$, Risteli J, et al. Congenital pseudarthrosis of neurofibromatosis type 1: impaired osteoblast differentiation and function and altered NF1 gene expression. Bone. 2009;44(2):243-250. doi:10.1016/j. bone.2008.10.050

17. Ghalayani P, Saberi Z, Sardari F. Neurofibromatosis type I ( von Recklinghausen 's disease ): A family case report and literature review. 2012;9(4):483-488.

18. Kuorilehto T, Poyhonen M, Bloigu R, Heikkinen J, Vaananen $\mathrm{K}$, Peltonen J. Decreased bone mineral density and content in neurofibromatosis type 1: lowest local values are located in the load-carrying parts of the body. Osteoporos Int. 2005;16(8):928-936. doi:10.1007/s00198.004.1801-4

19. Baden E, Jones JR, Khedekar R, Burns WA. Neurofibromatosis of the tongue: a light and electronmicroscopic study with review of the literature from 1849 to 1981 . J Oral Med. 1984;39(3):157-164.

20. Bongiorno MR, Pistone G, Arico M. Manifestations of the tongue in Neurofibromatosis type 1. Oral Dis. 2006;12(2):125-129. doi:10.1111/j.1601-0825.2005.01168.x

21. Zoller ME, Rembeck B, Oden A, Samuelsson M, Angervall L. Malignant and benign tumors in patients with neurofibromatosis type 1 in a defined Swedish population. Cancer. 1997;79(11):2125-2131.

22. Sailer, H. F., Kunzler, A., Makek, M. S. (1988). Neurofibrohämangiomatöse Weichteilveränderungen mit pathognomonischer Unterkieferdeformität. Fortschr Kief Gesichts Chirurgie, 33, 84-86.

23. Lorson EL, DeLong PE, Osbon DB, Dolan KD. Neurofibromatosis with central neurofibroma of the mandible: review of the literature and report of case. J Oral Surg. 1977;35(9):733-738.

24. Kaplan I, Calderon S, Kaffe I. Radiological findings in jaws and skull of neurofibromatosis type 1 patients. 
Dentomaxillofac Radiol. 1994;23(4):216-220. doi:10.1259/ dmfr.23.4.7835527

25. Visnapuu V, Peltonen S, Alivuotila L, Happonen R, Peltonen J. Craniofacial and oral alterations in patients with Neurofibromatosis 1. 2018:1-9.

26. Javed F, Ramalingam S, Bashir H, et al. Oral manifestations in patients with neurofibromatosis type-1:A comprehensive literature review. Crit Rev Oncol / Hematol. 2014;91(2):123129. doi:10.1016/j.critrevonc.2014.02.007

27. Friedrich RE, Giese M, Schmelzle R, Mautner V-F, Scheuer HA. Jaw malformations plus displacement and numerical aberrations of teeth in neurofibromatosis type 1: a descriptive analysis of 48 patients based on panoramic radiographs and oral findings. J Craniomaxillofac Surg. 2003;31(1):1-9.

28. Visnapuu V, Peltonen S, Ellila T. Periapical cemental dysplasia is common in women with NF1. 2007;50:274-280. doi:10.1016/j.ejmg.2007.04.001

29. Friedrich RE, Reul A. Periapical Cemento-osseous Dysplasia Is Rarely Diagnosed on Orthopantomograms of Patients with Neurofibromatosis Type 1 and Is Not a Gender-specific Feature of the Disease. Anticancer Res. 2018;38(4):22772284. doi:10.21873/anticanres. 12472

30. Epstein JB, Schubert MM, Hatcher DC. Multiple neurofibromatosis: Report of a case. Oral Surgery, Oral Med Oral Pathol. 1983;56(5):560-562. 